\title{
EFFECT OF TEMPERATURE ON GROWTH PERFORMANCE AND IMMUNOLOGICAL PARAMETERS OF GREATER AMBERJACK SERIOLA DUMERILI JUVENILES.
}

\author{
A. Fernández-Montero*, M.J. Caballero, S. Torrecillas, M.S. Izquierdo and D. Montero \\ Grupo de Investigación en Acuicultura (GIA), Instituto Ecoaqua. Universidad de Las Palmas de \\ Gran Canaria, Canary Islands, Spain.
}

\begin{abstract}
The greater amberjack Seriola dumerili (Risso 1810) is a marine pelagic species with a high interest for aquaculture due to its rapid growth and high commercial value. However, during grow out, monogenean parasites cause occasional mass mortalities in farmed fish and there is not so much published data on the optimum temperature for growth and immunological parameters of this fish species fingerlings.

Two hundred and twenty five juveniles were kept in triplicated in three experimental recirculated aquaculture system (RAS) at 17,22 and $26^{\circ} \mathrm{C}$, each RAS controlling 3 tanks. Fish were fed a commercial diet to apparent satiety during four months. Growth was monitored each month. At the end of the experimental period samples of intestine, skin, blood and skin mucus were obtained.

Growth, feed efficiency and immunological parameters, such as lysozyme and bactericidal activity have been studied to observe the relations between the different growth rates produced by the temperature and the immune system in serum and skin mucus. Besides, samples form skin and intestine were also obtained for histological studies, including the mucus production potential by analysing the goblet cells and the distribution of GALT in posterior intestine.

Fish held at $26^{\circ} \mathrm{C}$ presented the best growth and feed utilization, being the results obtained for immune potential discussed also in terms of temperature influence.
\end{abstract}

\section{Keywords}

Greater amberjack, Growth performance, Seriola dumerili, immune responses, mucosal immunity

*These authors have contributed equally to this work.

§Corresponding author. Tel.: +34 626568259

E-mail address: AlvaroFMontero@gmail.com 